\title{
Pengetahuan Gizi, Pola Makan, dan Kepatuhan Konsumsi Tablet Tambah Darah dengan Kejadian Anemia Remaja Putri
}

\author{
Retno Desita Putri ${ }^{1}$, Betty Yosephin Simanjuntak ${ }^{2}$, Kusdalinah $^{3}$ \\ ${ }^{1,2,3}$ Jurusan Gizi, Politeknik Kesehatan Kementerian Kesehatan Bengkulu \\ Email: putriretnodesita@gmail.com
}

\begin{abstract}
Knowledge of Nutrition, Diet, and Consumption of Fe Tablet Compliance with Anemia status of Girls Teenager. Anemia is a main nutritional problem in Indonesia, particularly iron deficiency anemia. The Government has been undertaking the giving the tablet for added blood. In Indonesia called Fe supplementation to prevent anemia. This study assessed the relationship of knowledge of nutrition, diet, and the compliance of consumption supplementation Fe to anemia status in MTsN 02 Bengkulu. This study used design cross-sectional and conducted in MTsN 02 Bengkulu. The population has taken teenage girl classes VII and VIII. The sample was gotten by using simple random sampling as much as 100 respondents taken from class VII and class VIII. The results showed that $37 \%$ of respondents anemia. There was a relationship of nutritional knowledge with anemia status $\mathrm{p}=0.018(\mathrm{p}<0.05)$, no relationship with a dietary status of anemia with results source of protein $\mathrm{p}=0.625$, a source of iron $\mathrm{p}=0.708$, and sources of vitamin $\mathrm{C}$ $\mathrm{p}=1.000(\mathrm{p}>0.05)$. There was a high associated anemia with the compliance of supplementation Fe $p=0.0005(p<0.05)$. The dominant variable is compliance Fe supplementation relationship with the of anemia in a teenage girl (61.55 times). School institution should make policy such as preparation time to consume Fe supplementation so that compliance can be improved.
\end{abstract}

Keywords: Compliance, Diet, Haemoglobin, Knowledge of nutrition, Teenage girl

\begin{abstract}
Abstrak: Pengetahuan Gizi, Pola Makan, dan Kepatuhan Konsumsi Tablet Fe dengan Kejadian Anemia Remaja Putri. Anemia adalah masalah gizi utama di Indonesia khususnya anemia defisiensi besi. Pemerintah telah menjalankan upaya pemberian tablet tambah darah (TTD) untuk menanggulangi anemia. Diketahui hubungan pengetahuan gizi, pola makan, dan kepatuhan konsumsi tablet Fe di MTsN 02 Kota Bengkulu. Penelitian ini menggunakan desain cross sectional dan dilakukan di MTsN 02 Kota Bengkulu. Populasi yang diambil remaja putri kelas I dan II. Pengambilan sampel dengan teknik simple random sampling, diperoleh 100 remaja putri yang memenuhi kriteria inklusi. Hasil penelitian menunjukkan bahwa 37\% responden mengalami anemia, hasil statistik menunjukkan bahwa ada hubungan pengetahuan gizi dengan status anemia $p=0,018(p<0,05)$, tidak ada hubungan pola makan dengan status anemia dengan hasil sumber protein $p=0,625$, sumber zat besi $p=0,708$, dan sumber vitamin $\mathrm{C} p=1,000(p>0,05)$. Ada hubungan kepatuhan konsumsi tablet Fe dengan status anemia $p=0,0005(p<0,05)$. Hasil multivariat variabel yang dominan yaitu kepatuhan konsumsi tablet Fe dengan peluang 61,55 kali. Ada hubungan pengetahuan gizi dan kepatuhan konsumsi tablet Fe dan tidak ada hubungan pola makan dengan status anemia pada remaja putri. Sebaiknya pihak sekolah membuat kebijakan penyediaan waktu untuk mengonsumsi tablet Fe agar kepatuhan dapat meningkat.
\end{abstract}

Kata kunci: Hemoglobin, Kepatuhan, Pengetahuan gizi, Pola makan, Remaja putri

Anemia adalah masalah gizi utama di Indonesia khususnya anemia defisiensi besi, yang paling banyak dialami oleh anak-anak sekolah khususnya remaja. Anemia adalah kekurangan zat gizi makro (protein) dan zat gizi mikro terutama zat besi.

Dampak anemia yang timbul pada remaja putri berdominan dengan menurunnya prestasi dan semangat belajar. Dampak kurangnya status besi (Fe) dapat mengakibatkan gejala seperti pucat, lesu/lelah, nafsu makan menurun serta gangguan pertumbuhan (Barasi, 2009).
Menurut World Health Organization (WHO), prevalensi anemia di dunia berkisar 40$88 \%$. Berdasarkan data Riskesdas tahun 2013, prevalensi anemia di Indonesia $21,7 \%$ dengan penderita anemia berumur 5-14 tahun sebesar $26,4 \%$ sedangkan penderita anemia berumur 1524 tahun sebesar 18,4\% (Kemenkes RI, 2011). Prevalensi anemia di Kota Bengkulu tahun 2013 pada remaja putri sebesar 43\% (Suryani, 2015). Wanita lebih beresiko terkena anemia terutama pada remaja putri. Di lain pihak remaja putri merupakan calon ibu yang bila tidak mencukupi 
kebutuhan Fe di masa remaja, akan berdampak di masa selanjutnya.

Beberapa faktor yang diduga mempengaruhi status anemia remaja diantaranya yaitu pengetahuan gizi, pola makan, dan kepatuhan konsumsi tablet Fe. Pengetahuan gizi adalah pemahaman mengenai makanan dan komponen zat gizi, sumber zat gizi pada bahan makanan, makanan yang aman dikonsumsi yang tidak menimbulkan penyakit serta cara untuk mengolah bahan makanan yang tepat agar kandungan zat gizi dalam bahan makanan tidak hilang serta pola hidup sehat.

Pola makan merupakan berbagai informasi yang memberikan gambaran mengenai macam dan jumlah bahan makanan yang dimakan tiap oleh satu orang dan merupakan ciri khas untuk suatu kelompok masyarakat tertentu. Pola makan adalah bagaimana cara suatu makanan diperoleh, jenis makanan yang dikonsumsi, atau frekuensi makan dari seseorang. Pola makan sering kali tidak teratur, jarang makan pagi maupun makan siang, akibatnya remaja putri sering lemas dan tidak semangat dalam proses belajar. Hal ini dikarenakan pada usia remaja sering berpola makan yang salah atau pembatasan makanan tinggi $\mathrm{Fe}$, pengetahuan ibu sebagai penyedia makanan di rumah tangga, pengetahuan remaja putri, pengaruh lingkungan, serta status gizi remaja tersebut (Suryani, 2015).

Kepatuhan adalah suatu perubahan perilaku dari perilaku yang tidak menaati peraturan ke perilaku yang menaati peraturan.Masalah kepatuhan merupakan kendala utama suplementasi besi harian, karena itu suplementasi mingguan sebagai alternatif untuk mengurangi masalah kepatuhan tersebut. Untuk menjaga kepatuhan konsumsi suplemen besi, dapat dilakukan dengan berbagai upaya seperti memberikan sosialisasi pada awal kegiatan, mengonsumsi suplemen besi langsung di depan petugas, dan mengirimkan pesan singkat kepada sampel penelitian (Sandra, 2004).

Penanggulangan anemia remaja putri dapat dilakukan melalui pemberian tablet tambah darah (TTD). Pemberian tablet tambah darah telah dilakukan oleh Dinas Puskesmas berupa 4 tablet yang dikonsumsi selama 1 bulan, setiap 1 tablet dikonsumsi selama 1 minggu.

Beberapa penelitian sebelumnya menunjukkan bahwa faktor-faktor yang mempengaruhi anemia diantaranya pengetahuan gizi, pola makan dan kepatuhan konsumsi tablet Fe. Hasil penelitian Zulaekah menyatakan bahwa jika pengetahuan gizi dipadukan dengan pemberian suplementasi besi terhadap remaja putri akan menghasilkan peningkatan kadar hemoglobin yang paling efektif dibandingkan dengan pengetahuan gizi saja atau pemberian suplementasi mingguan selama dua belas minggu (Zulaekah, 2007).

Remaja putri yang memiliki pola makan yang tidak baik berisiko 1.2 kali untuk menderita anemia disbanding remaja putri yang berpola makan yang baik (Suryani, 2015). Hasil yang sama dikemukakan oleh Yuniarti, dkk yang mengatakan bahwa ada hubungan yang bermakna antara kepatuhan minum tablet $\mathrm{Fe}$ dengan kejadian anemia pada remaja putri di MA Darul Imad kecamatan Tatah Makmur Kabupaten Banjar. Kepatuhan minum tablet $\mathrm{Fe}$ dipengaruhi oleh dua faktor utama, yaitu faktor dari petugas kesehatan dan faktor dari diri sendiri seperti kesadaran dalam mengkonsumsi tablet $\mathrm{Fe}$ (Yuniarti, 2015).

Namun hasil penelitian sebelumnya menunjukkan pengetahuan gizi tidak mempunyai hubungan dengan kejadian anemia (Ikhmawati, 2013).Hal ini mendasari penelitian untuk mengetahui hubungan pengetahuan gizi, pola makan dan kepatuhan konsumsi tablet Fe dengan kejadian anemia pada remaja putri di MTsN 02 Bengkulu.

\section{METODE}

Penelitian menggunakan desain cross sectional. Populasi adalah remaja putri kelas I dan II MTsN 02 Kota Bengkulu.Besar sampel dalam penelitian ini yaitu 100 remaja putri.Cara penentuan sampel dengan acak sederhana (simple random sampling). Kriteria inklusi yaitu remaja putri di MTsN 02 Kota Bengkulu, siswi kelas I dan II, remaja putri dengan usia 12 tahun sampai 15 tahun, remaja putri yang mengkonsumsi tablet $\mathrm{Fe}$ selama 4 minggu dan bersedia menjadi responden.

Data pengetahuan gizi didapatkan dengan menggunakan kuesioner penelitian.Pola makan didapatkan dengan menggunakan formulir FFQ. Data kepatuhan didapatkan dengan melihat bungkus tablet dan mewawancarai responden secara langsung menggunakan form catatan kepatuhan. Status anemia didapatkan dengan mengukur hemoglobin menggunakan alatukur hemoglobinometer digital (Easy Touch $\mathrm{GCHb}$ ) dengan hasil ukur 0 (anemia, $<12 \mathrm{mg} / \mathrm{dL}$ ) dan 1 (tidak anemia, $\geq 12 \mathrm{mg} / \mathrm{dL}$ ). Analisis data meliputi analisis univariat, analisis bivariat menggunakan uji Chi-square dan analisis multivariat menggunakan ujiregresi logistic. 
HASIL

Tabel 1. Distribusi Frekuensi Pengetahuan Gizi, Pola Makan, Kepatuhan Konsumsi Tablet Fe dan Status Anemia

\begin{tabular}{lrr}
\multicolumn{1}{c}{ Variabel } & Frek & \% \\
\cline { 1 - 2 } Pengetahuan Gizi & & \\
Kurang & 72 & 28 \\
Baik & & \\
Sumber Protein & 4 & 4 \\
Jarang & 96 & 96 \\
Sering & & \\
Sumber Besi (Fe) & 7 & 7 \\
Jarang & 93 & 93 \\
Sering & & \\
Sumber Vitamin C & 15 & 15 \\
Jarang & 85 & 85 \\
Sering & & \\
Kepatuhan Konsumsi Tablet Fe & 26 & 26 \\
Tidak Patuh & 74 & 74 \\
Patuh & & \\
Kejadian Anemia & 37 & 37 \\
Anemia & 63 & 63 \\
Tidak Anemia & & \\
\hline
\end{tabular}

Pada tabel 1 diketahui bahwa siswi SMP yang menjadi responden pada penelitian sebagian kecil memiliki pengetahuan gizi kurang, memiliki pola makan dengan sumber protein yang jarang dikonsumsi, memiliki pola makan dengan sumber zat besi yang jarang dikonsumsi, memiliki pola makan dengan sumber vitamin $\mathrm{C}$ jarang dikonsumsi, tidak mematuhi dalam mengkonsumsi tablet $\mathrm{Fe}$, dan memiliki status anemia dengan kategori anemia.

Tabel 2. Hubungan Pengetahuan Gizi, Pola Makan, dan Kepatuhan Konsumsi Tablet Fe dengan Status Anemia Remaja Putri

\begin{tabular}{|c|c|c|c|c|c|c|c|}
\hline \multirow[t]{3}{*}{ Variabel } & \multicolumn{4}{|c|}{ Kejadian Anemia } & \multicolumn{2}{|c|}{ Total } & \multirow[t]{3}{*}{$P$} \\
\hline & \multicolumn{2}{|c|}{ Anemia } & \multicolumn{2}{|c|}{$\begin{array}{c}\text { Tidak } \\
\text { Anemia }\end{array}$} & & & \\
\hline & $\mathbf{n}$ & $\%$ & $\mathbf{n}$ & $\%$ & $\mathbf{n}$ & $\%$ & \\
\hline \multicolumn{8}{|l|}{ Pengetahuan } \\
\hline \multicolumn{8}{|l|}{ Gizi } \\
\hline Kurang & 16 & 57,1 & 12 & 42,9 & 28 & 100 & 0,018 \\
\hline Baik & 21 & 29,2 & 51 & 70,8 & 72 & 100 & \\
\hline \multicolumn{8}{|l|}{ Pola Makan } \\
\hline \multicolumn{8}{|l|}{ Sumber Protein } \\
\hline Jarang & 2 & 50 & 2 & 50 & 4 & 100 & 0,625 \\
\hline Sering & 35 & 36,5 & 61 & 63,5 & 96 & 100 & \\
\hline \multicolumn{8}{|l|}{ Sumber Fe } \\
\hline Jarang & 3 & 42,9 & 4 & 57,1 & 7 & 100 & 0,708 \\
\hline Sering & 34 & 36,6 & 59 & 63,4 & 93 & 100 & \\
\hline \multicolumn{8}{|l|}{ Sumber Vit. C } \\
\hline Jarang & 6 & 40 & 9 & 60 & 15 & 100 & 1,000 \\
\hline Sering & 31 & 36,5 & 54 & 63,5 & 85 & 100 & \\
\hline \multicolumn{8}{|l|}{ Kepatuhan } \\
\hline Tidak patuh & 24 & 92,3 & 2 & 7,7 & 26 & 100 & 0,0005 \\
\hline Patuh & 13 & 17,6 & 61 & 82,4 & 74 & 100 & \\
\hline
\end{tabular}

Hasil analisis hubungan antara pengetahuan gizi dengan status anemia pada remaja putri diperoleh bahwa responden memiliki status anemia dengan kategori anemia memiliki pengetahuan gizi kurang, selain itu responden memiliki status anemia dengan kategori tidak anemia memiliki pengetahuan gizi kurang.

Hasil analisis hubungan antara pola makan dengan status anemia pada remaja putri diperoleh pola makan sumber protein memiliki status anemia dan status tidak anemia dengan pola makan jarang. Responden memiliki status anemia dengan pola makan sering dan responden memiliki status tidak anemia dengan pola makan sering. Pola makan sumber zat besi, responden memiliki status anemia dengan pola makan jarang dan responden memiliki status tidak anemia dengan pola makan jarang. Responden memiliki status anemia dengan pola makan sering dan responden memiliki status tidak anemia dengan pola makan sering. Pola makan sumber vitamin $\mathrm{C}$, responden memiliki status anemia dengan pola makan jarang dan responden memiliki status tidak anemia dengan pola makan jarang. Responden memiliki status anemia dengan pola makan sering dan responden memiliki status tidak anemia dengan pola makan sering.

Hasil analisis diperoleh pengetahuan gizi dan kepatuhan mengonsumsi tablet tambah darah memiliki hubungan signifikan dengan kejadian anemia masing-masing $p$ value nya 0.018 dan 0.0005 .Remaja putri yang memiliki pengetahuan baik $70.8 \%$ tidak mengalami anemia. Demikian juga remaja putri yang patuh mengonsumsi tablet tambah darah memiliki kadar hemoglobin di atas $11 \mathrm{gr} / \mathrm{dL}$ (tabel 2).

Tabel 3. Variabel yang Dominan terhadap Status Anemia Remaja Putri

\begin{tabular}{lcccc}
\multicolumn{1}{c}{ Variabel } & $\boldsymbol{P}$ & $\begin{array}{c}\text { Exp } \\
(\mathbf{B})\end{array}$ & \multicolumn{2}{c}{$\begin{array}{c}\mathbf{9 5 , 0 \%} \text { untuk Exp } \\
\text { (B) }\end{array}$} \\
\cline { 3 - 5 } & & & $\begin{array}{c}\text { Batas } \\
\text { Bawah }\end{array}$ & $\begin{array}{c}\text { Batas } \\
\text { Atas }\end{array}$ \\
\hline $\begin{array}{l}\text { Pengetahuan } \\
\text { Gizi }\end{array}$ & 0,025 & 3,951 & 1,187 & 13,150 \\
$\begin{array}{l}\text { Kepatuhan } \\
\text { Konsumsi } \\
\text { Tablet Fe }\end{array}$ & 0,00 & 61,555 & 12,277 & 308,635 \\
\hline
\end{tabular}

Berdasarkan tabel 3 diketahui bahwa yang menjadi faktor dominan terjadinya anemia pada remaja putri adalah ketidakpatuhan konsumsi tablet tambah darah yang dikonsumsi remaja putri berpeluang tinggi mengalami anemia dibanding remaja putri yang patuh. 


\section{PEMBAHASAN}

\section{Pengetahuan Gizi}

Terdapat hubungan yang signifikan antara pengetahuan gizi dengan kejadian anemia remaja putri. Penelitian ini sejalan dengan penelitian yang dilakukan oleh Ahmady bahwa pengetahuan yang baik berpengaruh terhadap status anemia remaja putri, pengetahuan tersebut bukan dari teori ilmu saja melainkan dari cara memilih bahan makanan demi dapat meningkatkan kadar hemoglobin agar status anemianya dalam kategori tidak anemia (Ahmady, 2016). Pengetahuan gizi sangat mempengaruhi kecenderungan remaja remaja putri dalam memilih sumber bahan makanan dengan nilai gizi yang tinggi zat besi. Selain itu pengetahuan gizi yang terfokus pada sumber bahan makanan yang menghambat penyerapan zat besi itu sangat penting, agar status anemia pada remaja putri dapat terkendali kearah normal.

Penelitian ini juga sejalan dengan penelitian yang dilakukan Royani menyatakan bahwa terdapat hubungan bermakna antara pengetahuan gizi dengan kejadian anemia untuk melihat status anemia pada remaja putri (Royani, 2011). Sementara hasil penelitian yang dilakukan Aditian menyatakan bahwa tidak terdapat hubungan yang bermakna secara statistik antara tingkat pengetahuan gizi remaja dengan status anemia. Namun terdapat kecenderungan remaja yang memiliki pengetahuan gizi rendah terkena anemia lebih tinggi dibandingkan yang memiliki pengetahuan tinggi (Aditian, 2009). Dalam hal ini pengetahuan gizi sangat mempengaruhi kecenderungan remaja putri dalam memilih sumber bahan makanan dengan nilai gizi yang tinggi zat besi.

\section{Pola Makan}

Hubungan pola makan dengan kejadian anemia tidak ada hubungan yang bermakna.Hal ini sejalan dengan penelitian yang dilakukan oleh Suryani menunjukkan tidak ada hubungan yang bermakna antara pola makan dengan kejadian anemia pada remaja putri (Suryani, 2015). Pada masa remaja yang memiliki pola makan tidak baik akan berisiko 1.2 kali untuk menderita anemia dibandingkan remaja putri yang memiliki pola makan yang teratur dan baik. Salah satu faktor yang dapat mempengaruhi kadar hemoglobin adalah asupan zat gizi dan pola makan yang kurang baik. Kurangnya asupan energi bersumber pada makronutrien dan mikronutrien akibat pola makan, sehingga dapat berkontribusi terhadap rendahnya kadar hemoglobin. Energi dibutuhkan dalam proses fisiologi tubuh, jika asupan energi kurang dapat menyebabkan terjadinya pemecahan protein sebagai sumber energi secara terus-menerus (Suryani, 2015).

Penelitian ini sejalan juga dengan penelitian Lewa mengatakan bahwa tidak ada hubungan antara asupan zat besi, protein dan vitamin $\mathrm{C}$ dengan kejadian anemia pada siswi MAN 2 Palu. Anemia pada siswi dikarenakan banyak responden jarang mengonsumsi bahan makanan yang mengandung zat besi, baik dari lauk hewani, protein maupun dari lauk nabati.Asupan zat besi masih di bawah $80 \%$ AKG, dimana rata-rata asupan zat besi hanya $12 \%$ dari AKG (Lewa, 2016).

Sumber besi merupakan makanan hewani, seperti ayam, daging dan ikan. Sumber yang lainnya yaitu telur, serealia tumbuk, kacangkacangan, sayuran hijau dan beberapa jenis buah. Selain jumlah zat besi yang harus diperhatikan, hal lain adalah kualitas makanan pada umumnya zat besi didalam ayam, daging dan ikan memiliki ketersediaan biologik sedang, dan besi yang berada didalam sayuran seperti bayam memiliki ketersediaan biologik rendah. Sebaiknya lebih diperhatikan untuk mengkombinasikan makanan sehari-hari, yang terdiri dari campuran sumber besi yang berasal dari hewan dan tumbuhtumbuhan serta sumber zat gizi lainnya yang dapat membantu absorpsi didalam tubuh (Sahlan, 2011).

Menghindari makanan yang mengandung tinggi protein hewani dapat menghambat pembentukan sel darah merah yang dapat mengakibatkan kekurangan zat besi sehingga kadar hemoglobin dibawah nilai normal dengan status anemia yang tidak normal pula. Kebanyakan remaja putri menganggap dirinya kelebihan berat badan atau kegemukan sehingga sering melakukan diet dengan cara yang tidak benar seperti pola makan yang tidak teratur, mengurangi frekuensi makan serta jumlah makan, memuntahkan kembali apa yang telah dimakan, akibatnya nafsu makan menurun dan sangat membahayakan diri mereka serta dapat berdampak dengan anemia. Pola makan yang tidak teratur seperti salah satunya mengkonsumsi protein hewani yang kurang akan menyebabkan turunnya kadar hemoglobin remaja putri dan berdampak pada anemia (Sandra, 2004).

\section{Kepatuhan Konsumsi Tablet Tambah Darah}

Terdapat hubungan yang signifikan antara kepatuhan konsumsi tablet $\mathrm{Fe}$ dengan kejadian 
anemia pada remaja putri. Penelitian ini sejalan dengan penelitian Yuniarti yang mengatakan bahwa ada hubungan yang bermakna antara kepatuhan minum tablet $\mathrm{Fe}$ dengan kejadian anemia pada remaja putri di MA Darul Imad kecamatan Tatah Makmur Kabupaten Banjar Tahun 2013 dengan hasil uji statistik uji chisquare diketahui $p=0,001$. Kepatuhan minum tablet tambah darah dipengaruhi oleh dua faktor utama, yaitu faktor dari petugas kesehatan dan faktor dari diri sendiri seperti kesadaran dalam mengkonsumsi tablet Fe. Kepatuhan dalam mengkonsumsi suplementasi zat besi atau pemberian tablet $\mathrm{Fe}$ sangat mempengaruhi perubahan kadar hemoglobin, dimana kadar hemoglobin yang normal maka status anemia juga akan normal, sehingga dapat mencegah dan menanggulangi anemia defisiensi besi (Yuniarti, 2015).

Penelitian Susanti Y, dkk menyatakan bahwa kepatuhan dalam mengkonsumsi suplementasi besi secara mingguan memiliki efektivitas yang sama terhadap suplementasi mingguan dan selama masa menstruasi dalam meningkatkan kadar hemoglobin pada remaja putri. Tingginya kepatuhan dalam mengkonsumsi suplementasi secara mingguan dapat meningkatkan kadar hemoglobin remaja putri. Berbagai penelitian menunjukkan bahwa kepatuhan dalam mengkonsumsi suplementasi mingguan dapat menghasilkan peningkatan kadar hemoglobin yang sama dengan mengkonsumsi suplementasi harian (Susanti, 2016).

\section{Hubungan Variabel Yang Paling Dominan}

Hasil multivariat diperoleh bahwa kepatuhan konsumsi tablet tambah Fe merupakan variabel yang paling dominan yang mempengaruhi kejadian anemia pada remaja putri adalah remaja putri yang tidak patuh mengonsumsi TTD berisiko 61,55 kali untuk menderita anemia dibanding remaja putri yang patuh mengonsumsi tablet tersebut. Hal ini berarti semakin banyak remaja putri yang patuh dalam mengkonsumsi tablet $\mathrm{Fe}$ maka peluang anemia semakin rendah. Sebaliknya jika ketidakpatuhan konsumsi tablet $\mathrm{Fe}$ rendah maka peluang kejadian anemia akan terus meningkat dikalangan remaja putri.

\section{SIMPULAN}

Sebanyak 37\% remaja putri mengalami anemia. Faktor yang berhubungan dengan kejadian anemia adalah pengetahuan dan kepatuhan mengonsumsi tablet tambah darah. Pengetahuan gizi yang baik akan berdampak pada pola makan seorang remaja yang baik serta kepatuhan dalam mengonsumsi tablet tambah darah sehingga perbaikan keadaan/prevalensi anemia remaja putridi Kota Bengkuluterutama di MTsN 02 dapat berkurang.

\section{SARAN}

Oleh karena itu perlu adanya kebijakan oleh pihak sekolah untuk menyediakan waktu secara bersama untuk mengkonsumsi tablet $\mathrm{Fe}$. Penyediaan waktu mengonsumsi tablet tambah darah secara bersama ini sebagai upaya meningkatkan kepatuhan siswi meminum tablet tersebut.

\section{DAFTAR PUSTAKA}

Aditian, N. 2009. Faktor-Faktor Yang Mempengaruhi Kejadian Anemia Gizi Remaja Putri SMP 133 Pulau Pramuka Kepulauan Seribu Tahun 2009. Skripsi, Jurusan Kesehatan Masyarakat Universitas Indonesia, Depok.

Ahmady, dkk. 2016. Penyuluhan Gizi Dan Pemberian Tablet Besi Terhadap Pengetahuan Dan Kadar Hemoglobin Siswi Sekolah Menengah Atas Negeri Di Mamuju. Jurnal Kesehatan Manarang, Vol.2, No.1. http://ejournal.poltekkesmamuju.ac.id/index.php/j km/ (Diakses tanggal 15 Januari 2017).

Barasi, M.E. 2009. At a Glance Ilmu Gizi. Jakarta: Erlangga.

Ikhmawati, Y. 2013. Hubungan Antara Pengetahuan Tentang Anemia Dan Kebiasaan Makan Terhadap Kadar Hemoglobin Pada Remaja Putri Di Asrama SMA MTA Surakarta. Prosiding Seminar Nasional Food Habit and Degenerative Diseases.

https://publikasiilmiah.ums.ac.id/bitstream/ handle/11617/2962/11_HUBUNGAN\%20 ANTARA\%20PENGETAHUAN\%20TEN TANG\%20ANEMIA.pdf?sequence $=1 \&$ is Allowed=y 
Kemenkes RI. 2011. Riset Kesehatan Dasar. Jakarta: Kementerian Kesehatan Republik Indonesia.

Sandra F, dkk. 2004. Pengaruh Suplementasi Zat Besi Satu dan Dua Kali Per Minggu Terhadap Kadar Hemoglobin Pada Siswi yang Menderita Anemia. Universa Medicina, Vol. 24 No. 4 (Diakses tanggal 11 Januari 2017).

Suryani Desri, dkk. 2015. Analisis Pola Makan Dan Anemia Gizi Besi Pada Remaja Putri Kota Bengkulu. Jurnal Kesehatan Masyarakat Andalas, Vol.10, No.1 Oktober 2015 (Diakses tanggal 10 Januari 2017).

Lewa, AF. 2016. Hubungan Asupan Protein, Zat Besi dan Vitamin C Dengan Kejadian Anemia Pada Remaja Putri Di MAN 2 Model Palu. Jurnal Publikasi Kesehatan Masyarakat Indonesia, Vol. 3 No. 1.

Royani. 2011. Faktor-Faktor Yang Berhubungan dengan Kejadian Anemia Pada Remaja Putri Di SMU Negeri Payakumbuh. Skripsi, FKM-UI, Depok.

Sahlan NU. 2011. Hubungan Pola Makan Dengan Status Hemoglobin (Hb) Ibu
Hamil di Kecamatan Tanete Rilau Kabupaten Barru. Skripsi, Universitas Hasanuddin: Makassar.

Susanti, Yeti, dkk. 2016. Suplementasi Besi Mingguan Meningkatkan Hemoglobin Sama Efektif Dengan Kombinasi Mingguan dan Harian pada Remaja Putri. Jurnal Gizi Pangan, Vol.11, No.1. http://journal.ipb.ac.id/index.php/jgizipang an/article (Diakses tanggal 12 Januari 2017).

Yuniarti, dkk. 2015. Hubungan Antara Kepatuhan Minum Tablet $\mathrm{Fe}$ Dengan Kejadian Anemia Pada Remaja Putri Di MA Darul Imad Kecamatan Tatah Makmur Kabupaten Banjar. Jurnal Publikasi Kesehatan Masyarakat Indonesia, Vol. 2, No. 1.

Zulaekah. 2007. Efek Suplementasi Besi, Vitamin C dan Pendidikan Gizi Terhadap Perubahan Kadar Hemoglobin Anak Sekolah Dasar Yang Anemia Di Kecamatan Kartasura Kabupaten Sukoharjo. Tesis, Program Pascasarjana Universitas Diponogoro Semarang. 